\title{
DET SER UT SOM ETT MUSEUM
}

Clara Åhlvik

It's like a museum, a critique of

museums, and a celebration of

museums - all rolled into one.

Maria Tucker, New York's New Museum.

The Museum of Jurassic Technology (MJT) är ett mycket litet museum som ligger på Venice Boulevard $i$ Los Angeles, mitt $i$ det anonyma bilgatulivet, omgärdat av kaféer och videobutiker. Vid fasaden en liten vattenfontän, som i Italien. En sluten dörr, en ringklocka. När vi ringer på klockan öppnas dörren av en ung kvinna och vi stiger in i en liten kombinerad reception och museibutik. Vi vandrar vidare in till utstälningarna.

MJT är ett museum som kan analyseras från flera utgångspunkter, inte minst en museal. Museet driver subtilt med det klassiska museet, dess strama upplägg, dess montrar fyllda med disparata ting och tillhörande utställningstexten som inte sällan förirrar sig i detaljer, rimligtvis utan intresse för någon utanför den ytterst begränsade krets som museimannen själv tillhör. MJT är kliniskt korrekt musealt, från montrarnas utformning och innehåll till tilltalet $\mathrm{i}$ utställningstexterna. Men innehållet skruvar, bryter, vrider och bitvis parodierar sina kusiner museerna. Det blir dock aldrig elakt. Snarare kännetecknas det av kärlek och ömsinthet, inte minst gentemot den traditionella museimakarens nära nog perversa fascination gentemot museiföremålen.

Ett bildspel introducerar museet och dess idémässiga grundval. Att förundras, att inte riktigt tro att det är sant, att häp- nas över det märkliga, det bisarra och det udda, kan sägas vara ett syfte med MJT.

Ett museum definieras som en samling av föremål och andra objekt av intresse för vetenskapen och bildningen. Det första kompletta naturhistoriska museet var Noaks Ark, som står som symbol för MJT. Men framförallt replierar museet på 161700-talens naturalie- och kuriosakabinett. Så nämns exempelvis i bildspelet samlingar som danska Museum Wormianum och renässansens "Wunderkammern» - furstar och kungars exklusiva privatsamlingar.

Museet är helt litet, utställningsytan är högst $150 \mathrm{kvm}$. Man börjar i de fasta utställningarna. De är överlag mycket välgjorda, traditionellt uppbyggda med stationer med text/monter/foto- arrangemang samt hörlurar. Det är hög finish på allt, snygg grafik, elegant ljussättning (mycket fiberoptik), välgjorda modeller, utsökta 
90 montrar med avancerade ljus- och spegeleffekter och flera bildspel.

Där berättas om stinkmyran, om karvade fruktstenar, om den amerikanska grårävens ylande, om Bernard Maston, Dionald $\mathrm{R}$ Griffith and the Deprong Mori of the Tripiscum Plateau, om rening genom sublimering, om hornet på Mary Davis of Saughalls bakhuvud. I ett rum visas brev som skickats till Mount Wilson Observatory - No One May Ever Have The Same Knowledge Again.

I The Delani/Sonnabend Hall berättas om Geoffrey Sonnabend, forskaren och författaren till verket «Obliscence: Theories of Forgetting and the Problem of Matter». Det berättas att Sonnabend, utmattad efter ett nervöst sammanbrott, vilade ut tillsammans med sin mor på en kurort i Argentina. En afton gick de på konsert för att lyssna till den berömda sångerskan Madalena Delani. När Sonnabend återvänt till hotellrummet efter konserten vandrar han sömnlös hela natten. Han får då idén till en Model of Obliscence, en modell för glömska. Modellen finns rekonstruerad i utställningen och så även en skildring av Madalena Delanis liv och leverne, med tillhörande klänning, sångprogram och noter. Delani och Geoffrey Sonnabend träffades aldrig. Hon dog nämligen tragiskt i en båtolycka bara fem dagar efter konserten.

Museet har tre tillfälliga utställningar om folklig övertro, om privatsamlingar från mobila hem och om Hagop Sandaldjians mikrominiatyrer.

I den förstnämnda, Tell the Bees: Belief, Knowledge and Hypersymbolic Cognition, beskrivs olika magiska/symboliska folktroföreställningar, där varje föreställning gestaltas i en monter med en förklarande text. Där finns ingen kronologi, ingen angivelse av källa, ort, år. Varje gestaltad föreställning står helt för sig själv och behandlar ämnen som $A$ Woman After Childbirth, Urine, Transmigration of Souls, Salted Teeth och Duck's Breath. Utställningens titel anspelar på människans förmåga att skapa ett förklaringens rum, söka ge en beskriving av världen, så lika i tid och rum att många föreställningar är desamma i olika kulturer och olika tider:

Like the bees, we are individuals, yet we are, most surely, like the bees, a group, and as a group we have over the millenia, built ourselves a hive, our

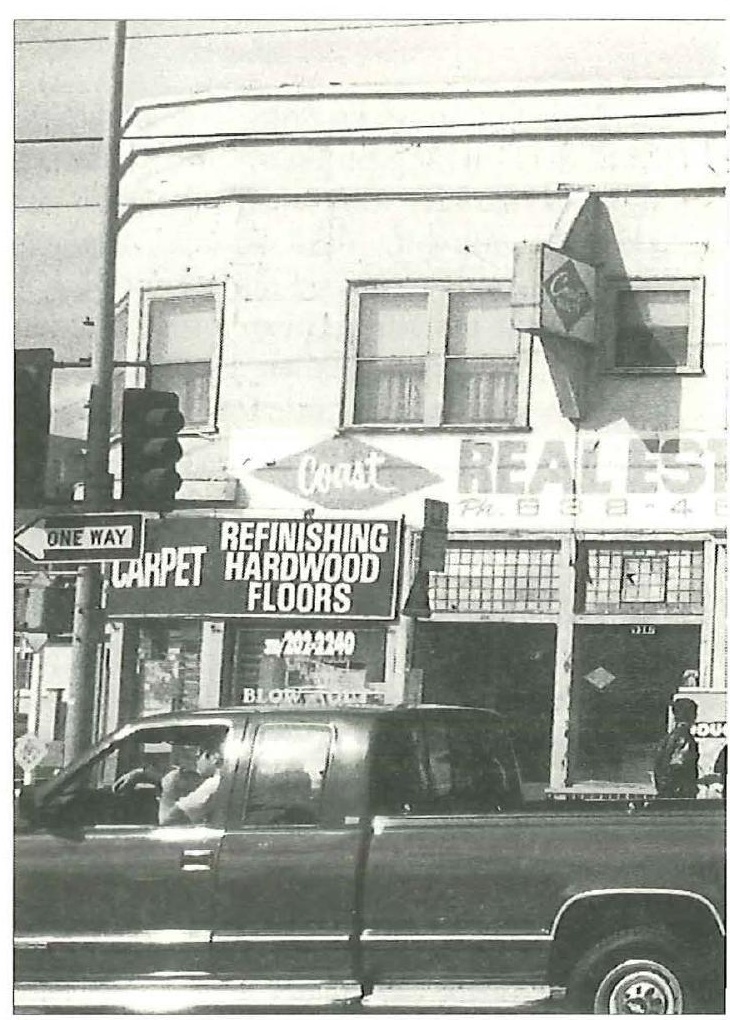


home. We would be foolish, to say the least, to turn our backs on this carefully and beautifully constructed home, especially now, in these uncertain and unsettling times. (ur katalogen Tell the Bees.1996)

Garden of Eden on Wheels. Selected Collections from Los Angeles Area Mobile Home and Trailer Parks visar sex samlingar från mobila hem i Los Angeles.

The Connie and Frank Schroer Collection består av över trehundra parfymflaskor, The Dixie Brown Collection är nåldynor medan The Isabel Jarboe Collection innefattar ett antal juvelträd, utförda av smycken och andra gnistrande ting. Varje sam- ling exponeras i montrar, formade som Noaks Ark. Samlarnas husvagnar finns med i modell.

I utställningen The Eye of the Needle. The unique World of Microminiatures of Hagop Sandaldjian tecknas ännu ett märkligt levnadsöde. Hagop Sandaldjian föds i Egypten 1931, flyttar som ung till Armenien, där han blir berömd violinist. När han 1980 flyttar till Los Angeles tar han upp den gamla armeniska traditionen att göra mikrominiatyrer gjorda av mänskliga hårstrån på nålsögon. I utställningen visas i mikroskop ett antal av hans miniatyrer, som Napoleon, Snövit och de sju dvärgarna, räven och kråkan. Ett litet, tek-

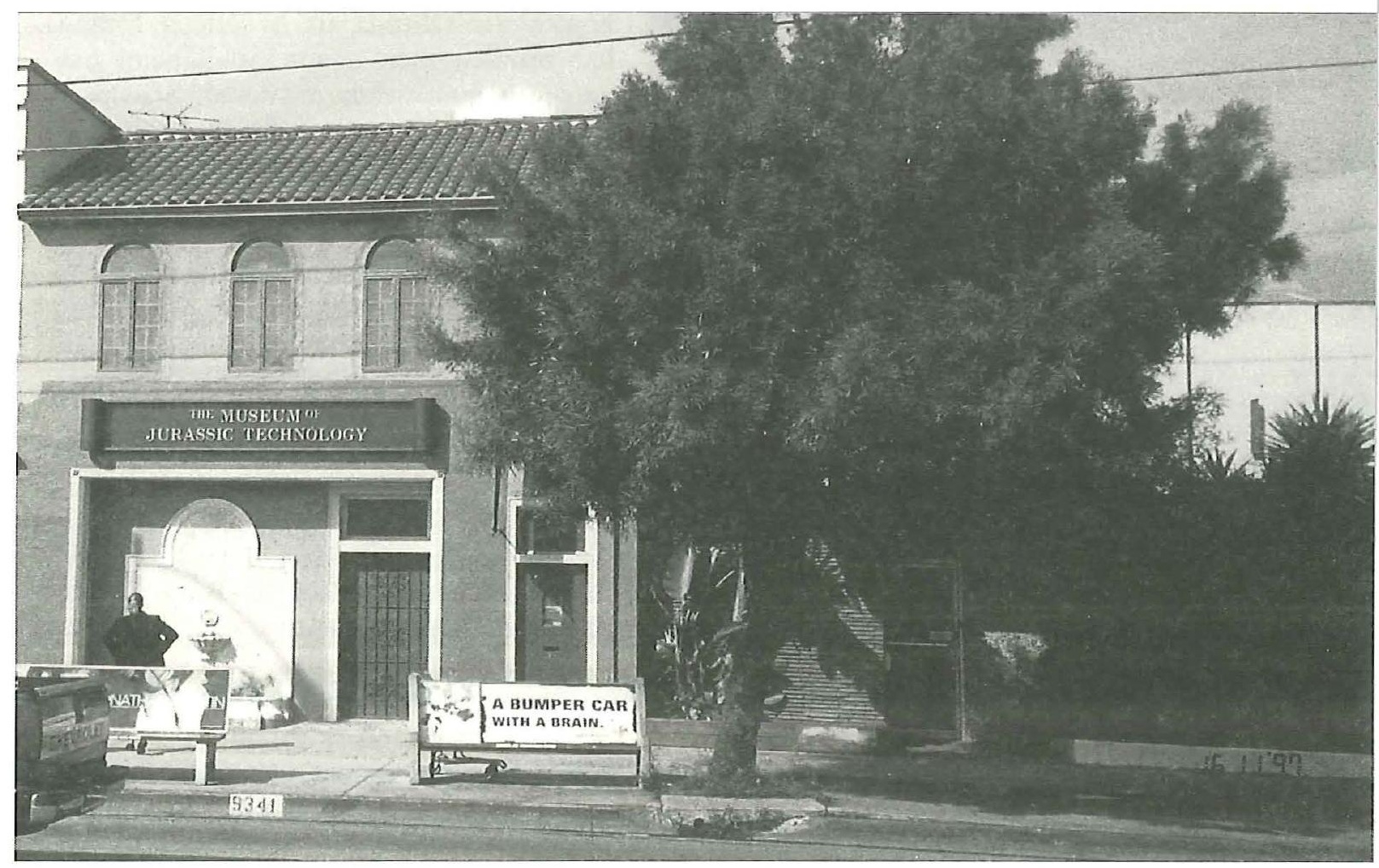




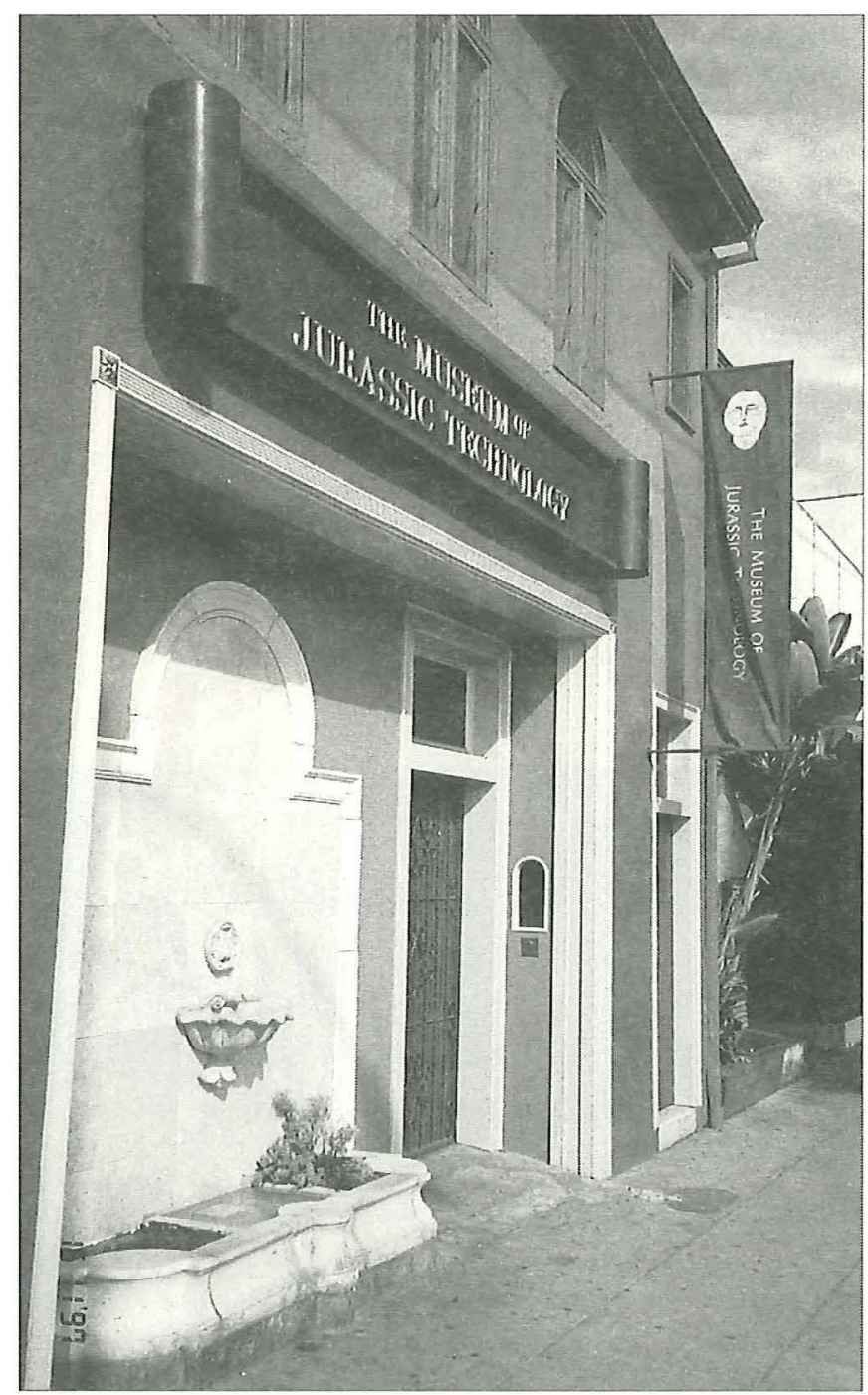

niskt mycket raffinerat bildspel, berättar om Hagops livsöde.

$\mathrm{Om}$ museets filosofi får man en glimt i katalogen The Eye of the Needle (1996).

Whenever we encounter some truly novel phenomenon, one that reinvents the margins of our world, an old hankering is awakened. At such moments we are like explorers of an unknown dimension: everything appears fresh to our eyes, each idea seems unprecedented, virgin, strange. In the face of this newly made universe, we may be tempted to exclaim «It cannot be!» yet our protests soon lie buried under an avalanche of wonder, and a desire to escape the narrow limits of our existence takes hold once again.

Och frågan väcks om sanningskriteriet vad är sant, på riktigt och helt och hållet? Kan detta vara sant? Författaren Lawrence Weschler funderar i boken Mr Wilson's Cabinet of Wonder (New York 1995) mycket över sanningsbegreppet, vad som faktiskt har funnits/finns på riktigt och vad som inte går att finna belägg för. Han konstaterar sålunda att Madalena Delani har funnits, men någon Sonnabend har han inte funnit dokumenterad. Självklart spelar det ingen roll. MJT är ett konstverk, en idé, en tanke där själva sanningsbegreppet är satt ur spel (ett sanningsbegrepp som dessutom bara existerar i museivärldens interna system. Hur äkta är museiföremålen i våra museer? Äkta i förhållande till vad?) Och spelar det någon roll om Geoffrey Sonnabend har funnits eller inte? Vi föreställer oss lätt alla dessa "Herr Sonnabend" som passerat genom historien. Dem som det aldrig blev någonting av, vars liv inte blev som de var tänkta, vars tankar och idéer aldrig slog rot. Lika verklig som Madame Bovary, som Karlsson i Hemsöborna...

Wunder - att förundras - att samla och visa det märkliga och det häpnadsväckande. MJT är en modern variant av Wunderkammern, som samlar och ställer ut det annorlunda, det misslyckade, det feltänkta, det som aldrig blev av. Museerna har 
länge valt att skildra normaliteten och ger därmed en homogen och slätstruken bild av människan: den typiske representanten för sin grupp, det må vara bonden, arbetaren, borgaren eller fiskaren. Men med denna museala stereotyp försvinner själva undret med att vara människa. I Museum of Jurassic Technology är det befriande att slippa normaliteten.

...guided along, as it were, a chain of flowers into the mysteries of life.
SUMMARY

It looks like a museum

A visit to The Museum of Jurassic Technology (MJT) in Los Angeles is the starting-point for a short questioning of the mixture of scientific truth and poetic fiction in museum collections and their presentations. The MJT uses the traditional presentational methods of museums in a manner that subtly unnerves the visitor because of the extraordinary and bizarre themes it treats. Exhibits are professionally displayed and lighted, commented on with the perverse predeliction for abstruse detail characteristic of museum curators. But it turns out that many of the narratives are fictional and the material evidence faked. It lookss to the marvels of the Renaissance cabinets of curiosities as a source of inspiration and argues that it is necessary to stimu-

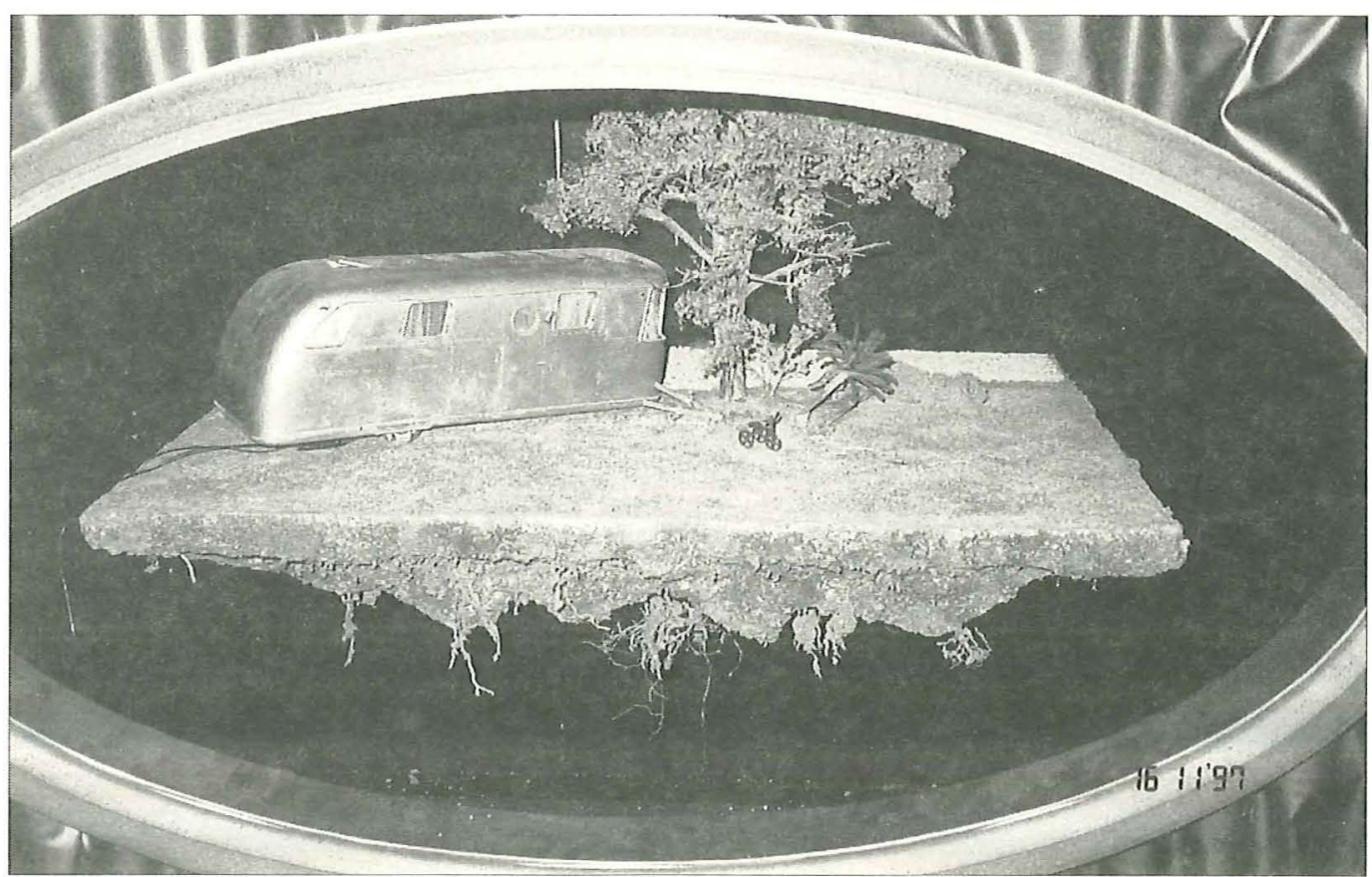

Modell av en husvagn frän utställningen "Garden of Eden of wheels». Alla foto: Clara Ählvik 1997. 
Clara $\AA$ HLVIK

94 late the visitor's reflections on the construction of truth in museums. It is, finally, a healthy reminder of the hazards of the curator's trade.

The Museum of Jurassic Technology 9341 Venice Boulevard, Culver City, Los Angeles, US

www.mjt.org

museumjt@rythm.com

Clara Ablvik är utställningschef vid BO 01.

Adr. BO 01 kansli, Valborgsgatan 10,

S-216 13 Malmö.

Fax: +46-40 362470. 